\title{
Sexual Precocity due to an Intracranial Tumour causing Unusual Testicular Secretion of Testosterone
}

\author{
J. S. M. HUTCHINSON, R. V. BROOKS, T. M. BARRATT, \\ C. G. H. NEWMAN, and F. T. G. PRUNTY \\ From St. Thomas's Hospital and Medical School, London
}

The involvement of hormone-secreting tumours in a wide range of pathological conditions is now becoming more completely understood (Noble, 1964). However, reports of tumours secreting hormones which influence sexual development are scarce. Stowell, Sachs, and Russell (1945) reported a case of a 15-year-old boy with a primary intracranial chorionepithelioma. Large quantities of human chorionic gonadotrophin (HCG)-like material were found in the urine, CSF, and tumour tissue, but signs of virilism were not reported. However, in a 7-year-old boy reported by Bruton, Martz, and Gerard (1961), development of precocious puberty was found to be attributable to a teratoma of the third ventricle which contained a chorionepithelioma, apparently secreting a similar substance. The present report concerns a study of sexual precocity of a 7-year-old boy attributable to a tumour in the brain, adjacent to the pineal, which contained large quantities of a luteinizing hormone (LH)-like material.

\section{Methods}

Height and weight data have been assessed by the method of Tanner (1958), and bone age determined by reference to the atlas of Greulich and Pyle (1950).

The testicular biopsy and interpretation were carried out as described by Clayton et al. (1966). Acetonedried tumour $(8 \mathrm{~g}$.) was extracted for gonadotrophins by the method of Steelman, Segaloff, and Mays (1958), as modified by Butt, Crooke, and Cunningham (1961). Urinary gonadotrophins were extracted by the method of Loraine and Brown (1959). The assays for 'total gonadotrophin', follicle stimulating hormone (FSH), and luteinizing hormone ( $\mathrm{LH})$ were carried out by the mouse uterus method (Klinefelter, Albright, and Griswold, 1943), the mouse augmentation method (Brown, 1955), and the ovarian ascorbic acid depletion (OAAD) method (Parlow, 1961), respectively. The results have been expressed (via a laboratory substandard): total gonadotrophin as mg. 1st IRP/HMG*

Received April 1, 1969.

* First international reference preparation for human menopausal gonadotrophin. per 24 hours, FSH and LH as i.u. 2nd IRP/HMG per 24 hours or per $\mathrm{g}$. Extracts, boiled to remove LH activity, were tested for $\mathrm{LH}$ releasing activity on their ability to release endogenous $L H$ in the OAAD assay. The calculation of results and tests of validity were performed by the methods of Gaddum (1953) and Borth (1960).

The testosterone production rate was measured by urinary isotope dilution by the method of Brooks $e t$ al. (1966), plasma testosterone by the method of Lim and Brooks (1965), and the cortisol secretion rate by a modification of the method of Brooks et al. (1963). Pregnanetriol was measured by the method proposed by the Medical Research Council Committee on Clinical Endocrinology (1963) and 17-oxosteroids (17-OS) and 17-oxogenic steroids (17-OGS) by the methods of Norymberski, Stubbs, and West (1953) and Appleby et al. (1955), respectively.

\section{Case Report}

The patient, aged 7 years 3 months, was admitted to St. Thomas's Hospital on July 27, 1965, for tonsillectomy. It was noted that he had a gruff voice and was large for his age, with height and weight on the 71st and 97th centile, respectively (Fig. 1). His mother stated that since the age of about 6 years 9 months she had noted an increase in his appetite, growth of his hands and feet, and penile enlargement. However, there was no pubic, axillary, or facial hair, and the testes were not enlarged. There were no signs of central nervous system disorder; he had normal visual fields and a normal sella turcica on $x$-ray. His bone age was assessed at $6 \frac{1}{2}$ years. Hormonal determinations made at this time are given in the Table.

In view of the obvious sexual development and the abnormally high gonadotrophin secretion, he was readmitted 2 months later, and kept under close study. Growth continued at a rate far exceeding the normal maximal pubertal rate of 7.0-15.5 cm. per year (Tanner, 1958) (Fig. 1). There had been an increase of $8.8 \mathrm{~cm}$. in 4 months. The bone age had advanced rapidly (Fig. 2) and was now assessed at 8-10 years, with the long bones showing development equivalent to that at 13 years. Pubic hair had appeared rapidly

+ Second international reference preparation for human menopausal gonadotrophin. 
TABLE

Hormonal Determinations

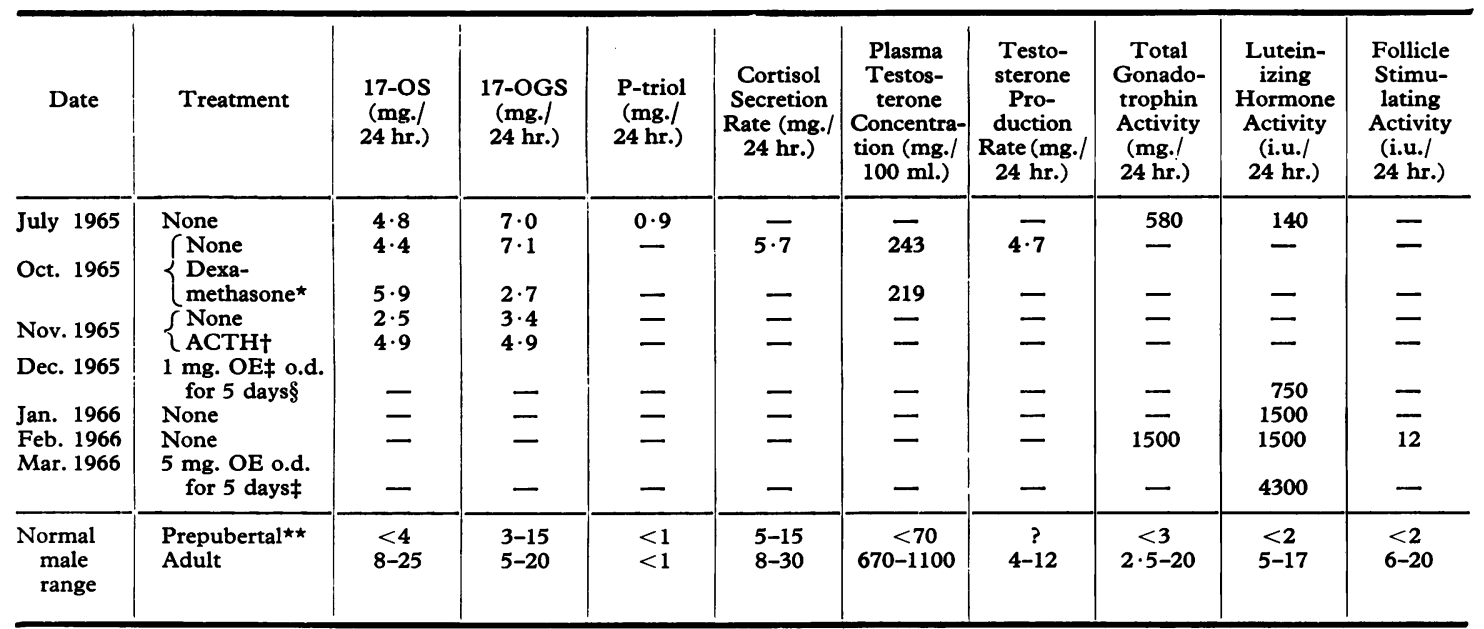

* Dexamethasone given $0.25 \mathrm{mg}$. 3 times a day o.m. for 2 days followed by $0.5 \mathrm{mg} .4$ times a day o.m. for 4 days. Mean excretion of 17-OS and 17-OGS on last 2 days and plasma testosterone concentration on penultimate day recorded.

† ACTH given 20 i.u. twice a day i.m. for 3 days. Maximum excretion of 17-OS and 17-OGS on any one of three days recorded.

$\ddagger \mathrm{OE}$ is ethyl oestradiol.

$\S \mathrm{LH}$, Luteinizing hormone activity measured on last day of treatment.

$\star \star$ Provisional figures based on limited data from many sources (see discussion).

and there had been a further penile growth to $8 \mathrm{~cm}$. The scrotum had enlarged but the testes were disproportionately small considering the degree of somatic development, the long axis being $2.5 \mathrm{~cm}$. No spermatozoa could be detected in repeated specimens of urine.

Hormonal determinations and the results of dexamethasone suppression and corticotrophin stimulation tests carried out in October are given in the Table.

Air encephalography was normal. His appearance on November 21, 1965, is shown on Fig. 3. In order to exclude any possibility of an adrenal tumour, both adrenals were explored on November 30, 1965, and found to be normal. A testicular biopsy taken at this time showed gross interstitial cell hyperplasia with some tubular maturation (Fig. 4). There was proliferation of spermatogonia and primary spermatocytes and occasional secondary spermatocytes, but no spermatids or spermatozoa were present.

Over the next 5 months (December-April) growth was still abnormal, but less so than previously (an increase of $5.4 \mathrm{~cm}$.). In order to test the involvement of the hypothalamo-pituitary axis in the excessive gonadotrophin excretion, attempts were made to block this axis with ethinyl oestradiol (see Table). The excretion of LH activity continued to rise whether ethinyl oestradiol was given or not. The excretion of FSH activity measured in February under resting conditions was, however, only 12 i.u. per 24 hours.

In May 1966, symptoms of raised intracranial pressure developed. Electroencephalography confirmed the likelihood of a mid-brain lesion, and an air encephalogram then revealed a large tumour in the region
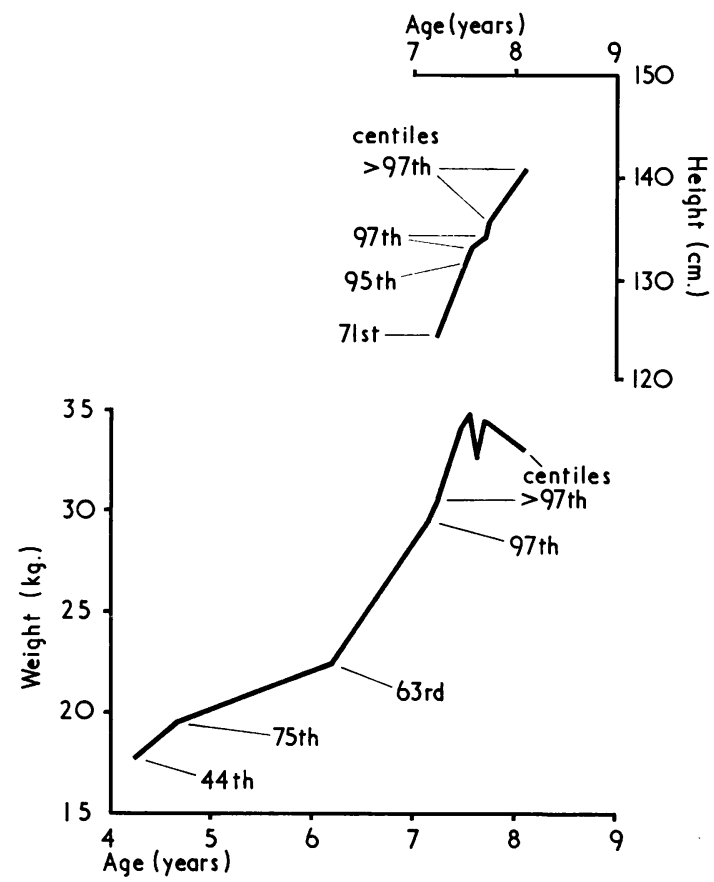

FIG. 1.-Changes in height and weight (including the centile status). 


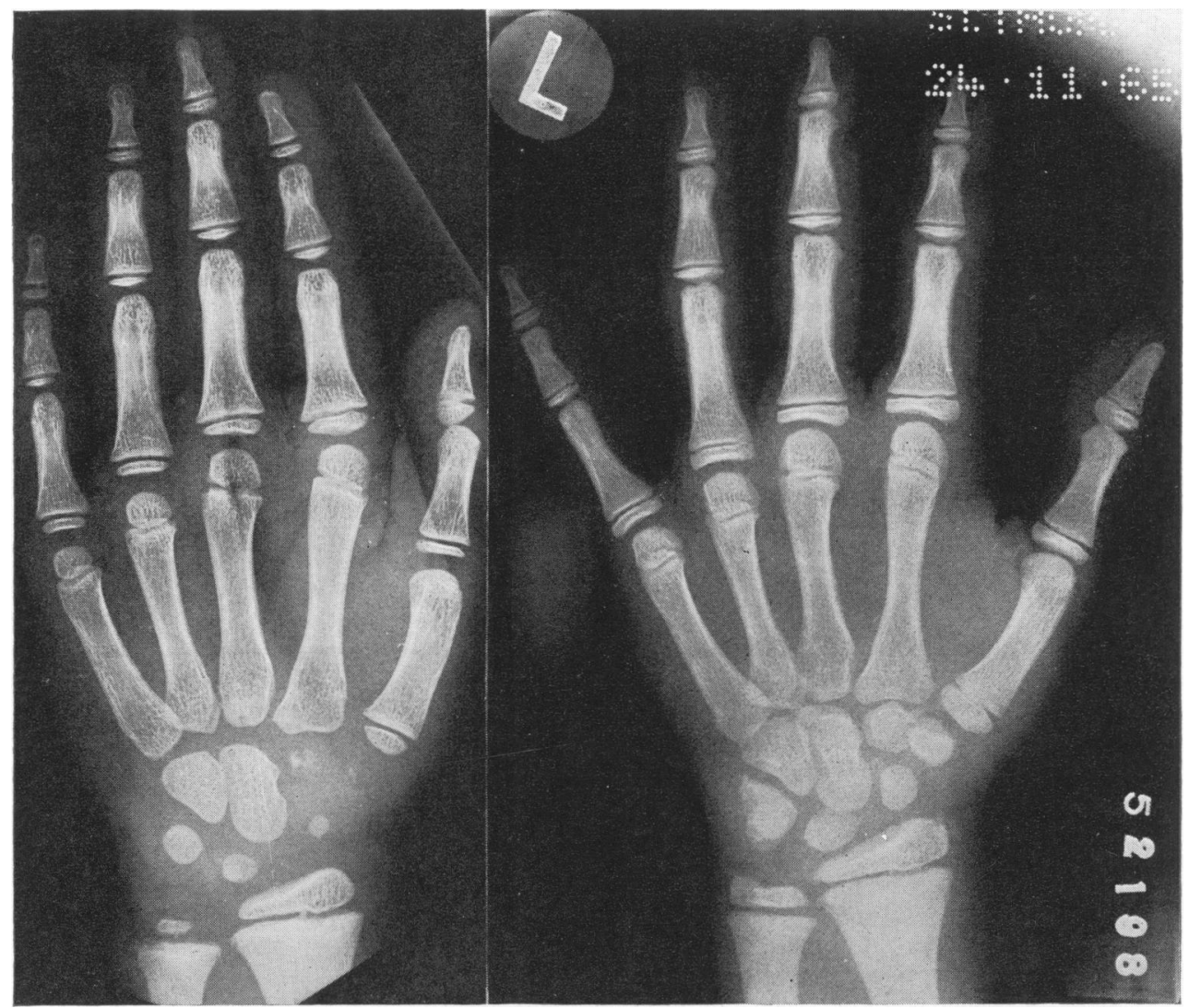

FIG. 2.-X-rays of left wrist taken in July 1965 (left) and November 1965 (right).

of the pineal. A left side Torkildsen operation was performed and this temporarily improved his general condition, but in spite of radiotherapy he rapidly deteriorated and died a month later.

At necropsy, a large central tumour was present in the brain-stem area extending laterally into the hypothalamic regions of both sides. The tumour was largely necrotic and haemorrhagic, and contained only a few small nests of viable cells. Some of these consisted of tightly packed, polygonal cells with a faintly basophilic cytoplasm and round vesicular nuclei with prominent nucleoli. In other cell groups similar cells, but larger and often containing more than one nucleus, were intermingled with darker multinucleated giant cells. The latter had an eosinophilic cytoplasm and numerous hyperchromatic nuclei with a dense chromatic pattern. The appearances of the 2 cell types resembled the cytotrophoblast and syncytiotrophoblast of chorionic tumours, and the tumour was considered a chorioncarcinoma (Fig. 5). Assay of the tumour revealed a content of $\mathrm{LH}$ activity equivalent to $1200 \mathrm{i}$.u. per $\mathrm{g}$. and of FSH activity of $1 \cdot 2$ i.u. per g. After heating to $100{ }^{\circ} \mathrm{C}$., no LH-like activity could be detected. The pituitary and adrenal glands appeared normal.

\section{Discussion}

The data indicate clearly that this was a case of sexual precocity due to an excessive stimulation of the interstitial cells of the testes by a substance produced by the intracranial tumour. The remarkable increase in growth rate and appearance of secondary sexual characters linked with an abnormally high gonadotrophic-like excretion, which was up to at least 50 times the normal adult level (Hutchinson, Worden, and Prunty, 1965), and of LH activity, which was at least 250 times the normal adult level (Prunty et al., 1969), indicated that a pathological process other than a premature activation of the normal pubertal changes had occurred.

The results of the steroid analyses showed that 17-OS and 17-OGS were raised for the patient's chronological age (Borth, Linder, and Riondel, 1957; Prunty, 1964; Margraf and Weichselbaum, 1967), though probably normal for his state of physical development. There was a normal cortisol secretion 


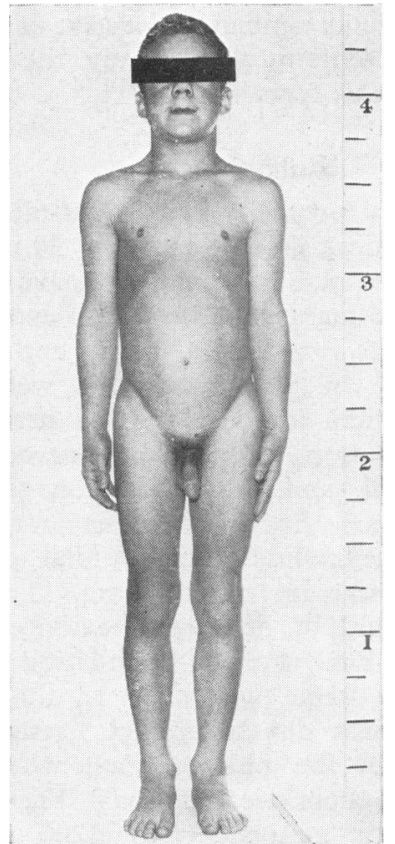

Fig. 3.-Patient aged 7 years 7 months, November 1965.

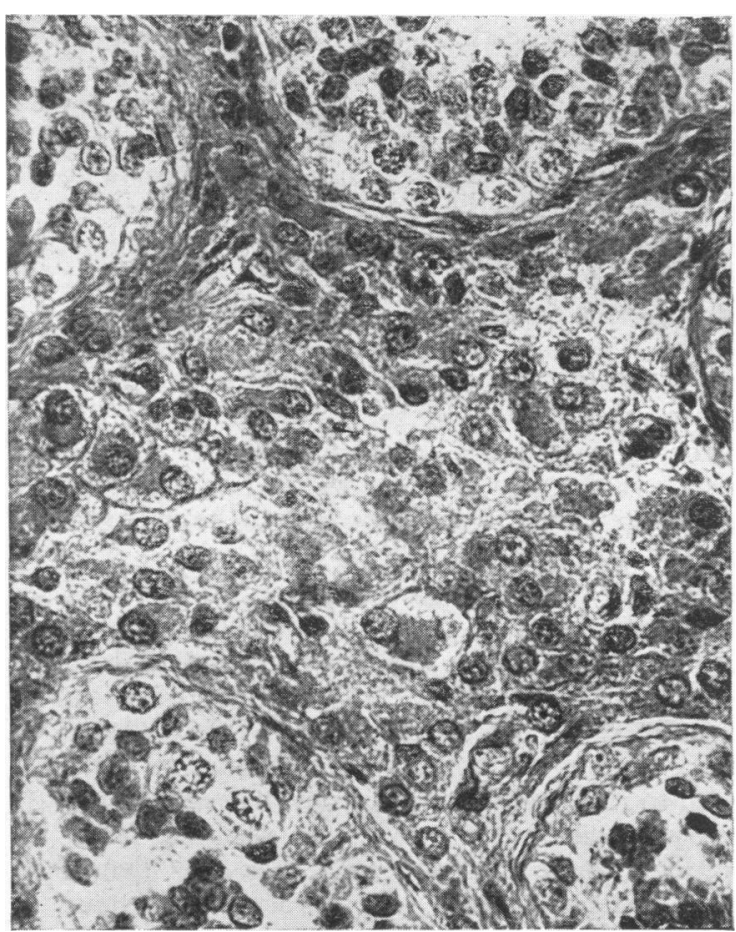

FIG. 4.-Section of testis (H. and E. $\times 405)$.

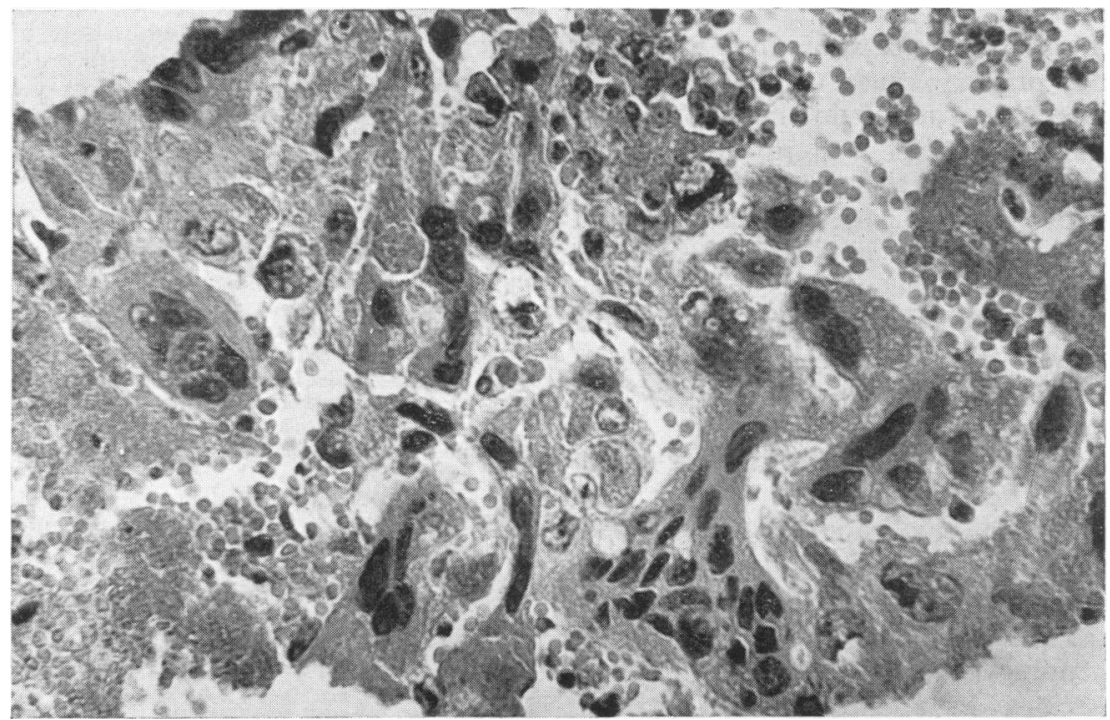

FIG. 5.-Section of tumour showing several multinucleate syncytiotrophoblast cells interspersed with smaller cytotrophoblastic cells $(H$. and $E . \times 405)$. 
rate (see Makin, Edwards, and Clayton, 1968) and a normal suppression of 17-OGS by dexamethasone. Fractionation of the 17-OS was compatible with the principal androgen produced being testosterone. Plasma testosterone was raised and reached a value higher than that found in 5 normal boys of 12 and 13 years studied here (R.V.B.). The testosterone production rate was within the lower limit of values for normal men (Korenman, Wilson, and Lipsett, 1963). Both the plasma testosterone and 17-OS were unaffected by dexamethasone suppression and hence were not thought to be primarily under ACTH control. The absence of an autonomous adrenal lesion was confirmed, so that the gross interstitial cell hyperplasia in the testis appeared to be the sole source of the androgen.

Attempts to block the excretion of the $\mathrm{LH}$ activity with ethinyl oestradiol, which has been shown to lower serum LH levels in normal men (Odell, Ross, and Rayford, 1966; Peterson, Midgley, and Jaffe, 1968), completely failed. This evidence and the finding of a normal pituitary fossa on $x$-ray tended to rule against pituitary involvement; either directly or via an abnormality in releasing-factor secretion. In spite of the initial lack of evidence, by air encephalography, an intracranial tumour which was producing an LH-like material was thus suspected. This was not confirmed until 2 months later by air encephalography and at necropsy. On histological evidence the tumour was considered to be a chorion-carcinoma. The finding of very large quantities of an LH-like material, which was not releasing factor, in the tumour, thus indicated that it was the primary cause of the endocrine changes. The exact nature of this material is unresolved. Measurable FSH was present in the tumour and the LH: FSH ratio was lower than that found in the urine of a patient with chorionepithelioma of the testes or in HCG. However, the possibility of interference in the augmentation assay by the very high LH-like levels cannot be excluded. The LH : FSH ratio of the gonadotrophins found in the urine was much lower than that subsequently found in the tumour. This suggests either a different rate of release of the 2 gonadotrophins from the tumour, or that the abnormal balance in the patient caused some release of gonadotrophin from the pituitary.

Teratomata associated with precocious sexual development in the male are rare. A presacral teratoma containing androgen-producing tissue has been described in a 9-month-old boy by Rhoden (1944), and Bruton et al. (1961) studied a case of precocious puberty in a 7-year-old boy due to a chorionepithelioma of the brain. The case described here seems similar to the case of Bruton et al. and represents probably only the second recorded case of this type.

\section{Summary}

A case of sexual precocity in a 7-year-old boy is described. His peak growth rate was $26 \mathrm{~cm}$. per year. The appearances of secondary sexual characteristics and bone maturation were also excessively rapid. The testes remained at a size appropriate to his age, but the interstitial cells were very hyperplastic. There was evidence of near adult testosterone secretion; plasma testosterone was $243 \mathrm{~m} \mu \mathrm{g} . / 100 \mathrm{ml}$. and the production rate was $4.7 \mathrm{mg} . / 24 \mathrm{hrs}$. Spermatogenesis was only slightly accelerated. Excretion of total gonadotrophic activity was up to $1500 \mathrm{mg}$. 1st IRP/ HMG/24 hrs., and of luteinizing activity up to 4400 i.u. LH/24 hrs. Follicle-stimulating activity excretion in the urine was only 12 i.u. FSH/ $24 \mathrm{hrs}$. Death was due to a large haemorrhage into a tumour in the pineal region which was considered to be a chorion-carcinoma. The tumour contained activity equivalent to 1200 i.u. of luteinizing hormone and $1 \cdot 2$ i.u. of $\mathrm{FSH} / \mathrm{g}$. dry weight.

We wish to thank Dr. B. D. R. Wilson for permission to study his patient; Dr. J. M. Tanner for advice on the height and weight curves, testicular size, and bone age; Dr. J. R. Tighe for histological examination of the testicular biopsy; Professor H. Urich and Dr. H. R. M. Johnson for histological examination of the tumour; Mr. K. Till for the air encephalography and the Torkildsen operation; Dr. J. A. Loraine for help and advice with the gonadotrophin assays; and Dr. D. R. Bangham for the gifts of 1st and 2nd IRP/HMG used to standardize the gonadotrophin assays.

\section{REFERENCES}

Appleby, J. I., Gibson, G., Norymberski, J. K., and Stubbs, R. D. (1955). Indirect analysis of corticosteroids. I. The determination of 17-hydroxycorticosteroids. Biochem. F., 69, 453.

Borth, R. (1960). Simplified mathematics for multiple bioassays. Acta endocr. (Kbh.), 35, 454.

- Linder, A., and Riondel, A. (1957). Urinary excretion of 17-hydroxy-corticosteroids and 17-ketosteroids in healthy subjects, in relation to sex, age, body weight and height. ibid., 25, 33.

Brooks, R. V., Dupré, J., Gogate, A. N., Mills, I. H., and Prunty, F. T. G. (1963). Appraisal of adrenocortical hyperfunction; patients with Cushing's syndrome or 'non-endocrine' tumors. 7. clin. Endocr., 23, 72 ;.

, Jeffcoate, S. L., London, D. R., Prunty, F. T. G., and Smith, P. M. (1966). Studies of ovarian androgen secretion. In Androgens in Normal and Pathological Conditions. Proc. IInt Symp. on Steroid Hormones, Ghent, fune 17-19, 1965. Excerpta med. (Amst.), int. Congr. Ser., 101, 103.

Brown, P. S. (1955). The assay of gonadotrophin from urine of non-pregnant human subjects. $\mathcal{F}$. Endocr., 13, 59.

Bruton, O. C., Martz, D. C., and Gerard, E. S. (1961). Precocious puberty due to secreting chorionepithelioma (teratoma) of the brain. F. Pediat., 59, 719. 
Butt, W. R., Crooke, A. C., and Cunningham, F. J. (1961). Studies on human urinary and pituitary gonadotrophins. Biochem. $\mathcal{F}$., 81, 596.

Clayton, B. E., Hutchinson, J. S. M., Hyde, R. D., London, D. R., Mills, I. H., and Prunty, F. T. G. (1966). A study of the classification of male hypogonadism with observations on the control of 17-oxosteroid precursors from the testes and adrenals F. Endocr., 34, 507.

Gaddum, J. H. (1953). Simplified mathematics for bioassays. 7. Pharm. Pharmacol., 5, 345.

Greulich, W. W., and Pyle, F. I. (1950). Radiographic Atlas of Skeletal Development of the Hand and Wrist. Stanford University Press, Stanford, U.S.A.

Hutchinson, J. S. M., Worden, J. M., and Prunty, F. T. G. (1965). Urinary gonadotrophin excretion in hypogonadal men. 7. Endocr., 32, 237.

Klinefelter, H. F., Jr., Albright, F., and Griswold, G. C. (1943). Experience with a quantitative test for normal or decreased amounts of follicle stimulating hormone in the urine in endocrinological diagnosis. F. clin. Endocr., 3, 529.

Korenman, S. G., Wilson, H., and Lipsett, M. B. (1963). Testosterone production rates in normal adults. $\mathcal{f}$. clin. Invest., 42, 1753.

Lim, N. Y., and Brooks, R. V. (1965). A modification of the $\left.{ }^{35} \mathrm{~S}\right]$ thiosemicarbazide method for the estimation of plasma testosterone. Steroids, 6, 561 .

Loraine, J. A., and Brown, J. B. (1959). A method for the quantitative determination of gonadotrophins in the urine of nonpregnant human subjects. F. Endocr., 18, 77.

Makin, H. L. J., Edwards, R. W. H., and Clayton, B. E. (1968). Cortisol production rates in children. Clin. Sci., 34, 549.

Margraf, H. W., and Weichselbaum, T. E. (1967). Laboratory procedures in diagnosis of adrenal cortical diseases. In The Adrenal Cortex, p. 405. Ed. by A. B. Eisenstein. Little, Brown, Boston. Churchill, London.

Medical Research Council Committee on Clinical Endocrinology (1963). A standard method of estimating 17-oxosteroids and total 17-oxogenic steroids. Lancet, 1, 1415.
Noble, R. L. (1964). Tumors and hormones. In The Hormones, vol. 5, p. 559. Ed. by G. Pincus, K. V. Thimann, and E. B. Astwood. Academic Press, New York.

Norymberski, J. K., Stubbs, R. D., and West, H. F. (1953). Assessment of adrenocortical activity by assay of 17 -ketogenic steroids in urine. Lancet, 1, 1276.

Odell, W. D., Ross, G. T., and Rayford, P. L. (1966). Radioimmunoassay for human luteinizing hormone. Metabolism, 15, 287.

Parlow, A. F. (1961). In Human Pituitary Gonadotrophins, p. 300. Ed. by A. Albert. Thomas, Springfield, Illinois.

Peterson, N. T., Jr., Midgley, A. R., Jr., and Jaffe, R. B. (1968), Regulation of human gonadotrophins. III. Luteinizing hormone and follicle stimulating hormone in sera from adult males. F. clin. Endocr., 28, 1473.

Prunty, F. T. G. (1964). Chemistry and Treatment of AdrenoCortical Disease, p. 95. Thomas, Springfield, Illinois.

-, Davidson, N. McD., Hutchinson, J. S. M., and Reid, D. J. (1969). Investigations on male hypogonadism. Proc. roy. Soc. Med., 62, 27.

Rhoden, A. E. (1944). Precocious sexual and somatic development in a male infant with presacral teratoma containing androgenproducing tissue. 7. clin. Endocr., 4, 185.

Steelman, S. L., Segaloff, A., and Mays, M. G. (1958). Preparation of highly active human gonadotrophin and growth hormone. Arch. Biochem., 78, 262.

Stowell, R. E., Sachs, E., and Russell, W. O. (1945). Primary intracranial chorionepithelioma with metastases to the lungs. Amer. F. Path., 21, 787.

Tanner, J. M. (1958). The evaluation of physical growth and development. In Modern Trends in Pediatrics, second series, p. 325. Ed. by A. Holzel and J. P. M. Tizard. Butterworth, London.

Correspondence to Dr. J. S. M. Hutchinson, Department of Chemical Pathology, St. Thomas's Hospital Medical School, London S.E.1. 